\title{
PRINSIP-PRINSIP PENGEMBANGAN KURIKULUM
}

\author{
Bradley Setiyadi ${ }^{1}$, Revyta $^{2}$, Ayunda Fadhilah ${ }^{3}$ \\ Program Studi Administrasi Pendidikan FKIP Universitas Jambi, email: \\ bradleysetiyadi@unja.ac.id \\ Program Studi Administrasi Pendidikan FKIP Universitas Jambi, email: \\ revyta25vita@gmail.com \\ Program Studi Administrasi Pendidikan FKIP Universitas Jambi, email: \\ syakirakira149@gmail.com
}

\begin{abstract}
The curriculum is the core of the education process in schools. The implementation of the curriculum directly influences the educational outcomes. The curriculum really determines the process and results of an education system. The curriculum is a description of the material presented in learning, is also a very important component in an education system, the curriculum is a tool to achieve educational goals and at the same time as a guide in the implementation of teaching at all types and levels of education. Curriculum development is a process that plans, produces a better tool based on the results of an assessment of the curriculum that has been in effect, so that it can provide good teaching and learning conditions. In other words curriculum development is an activity to produce a new curriculum through the steps of curriculum preparation based on the results of the assessment conducted over a certain period of time. Curriculum principles can also be regarded as rules that animate curriculum development. This principle has the aim that the curriculum is designed or produced in accordance with the demands of all parties, namely students, parents, community and nation. In general, curriculum experts view curriculum development activities as a continuous process, a cycle that involves several curricula, namely components, objectives, materials, activities and evaluations. This paper uses the method of theoretical study of the principles of curriculum development. The theories put forward in this paper are understanding the curriculum and its developers, plus theories about the sources and principles of curriculum development, learning and evaluation of curriculum development.
\end{abstract}

Keywords: curriculum concept, curriculum development, curriculum principles

\begin{abstract}
ABSTRAK
Kurikulum merupakan inti dari proses pendidikan di sekolah. Pelaksanaan kurikulum langsung berpengaruh terhadap hasil pendidikan. Kurikulum sangat menentukan proses dan hasil suatu sistem pendidikan. Kurikulum merupakan jabaran materi-materi yang disajikan dalam pembelajaran, juga merupakan komponen yang sangat penting dalam suatu sistem pendidikan, kurikulum merupakan alat untuk mencapai tujuan pendidikan
\end{abstract}


dan sekaligus sebagai pedoman dalam pelaksanaan pengajaran pada semua jenis dan tingkat pendidikan. Pengembangan kurikulum adalah sebuah proses yang merencanakan, menghasilkan suatu alat yang lebih baik dengan didasarkan pada hasil penilaian terhadap kurikulum yang telah berlaku, sehingga dapat memberikan kondisi belajar mengajar yang baik. Dengan kata lain pengembangan kurikulum adalah kegiatan untuk menghasilkan kurikulum baru melalui langkah-langkah penyusunan kurikulum atas dasar hasil penilaian yang dilakukan selama periode waktu tertentu. Prinsip kurikulum dapat juga dikatakan sebagai aturan yang menjiwai pengembangan kurikulum. Prinsip tersebut mempunyai tujuan agar kurikulum yang didesain atau dihasilkan sesuai dengan permintaan semua pihak yakni anak didik, orang tua, masyarakat dan bangsa. Pada umumnya ahli kurikulum memandang kegiatan pengembangan kurikulum sebagai suatu proses yang berkesinambungan, merupakan suatu siklus yang menyangkut beberapa kurikulum yaitu komponen, tujuan, bahan, kegiatan dan evaluasi. Tulisan ini menggunakan metode berupa kajian teori mengenai prinsip pengembangan kurikulum. Teori-teori yang dikemukakan dalam tulisan ini adalah pengertian kurikulum dan pengembangnya, ditambah teori mengenai sumber dan prinsip pengembangan kurikulum, pembelajaran serta evaluasi dari pengembangan kurikulum.

Kata kunci: konsep kurikulum, pengembangan kurikulum, prinsip kurikulum

\section{PENDAHULUAN}

Kurikulum merupakan jabaran materi-materi yang disajikan dalam pembelajaran, juga merupakan komponen yang sangat penting dalam suatu sistem pendidikan, kurikulum merupakan alat untuk mencapai tujuan pendidikan dan sekaligus sebagai pedoman dalam pelaksanaan pengajaran pada semua jenis dan tingkat pendidikan. Dalam dunia pendidikan kurikulum bisa diartikan secara sempit maupun secara luas. Secara sempit kurikulum diartikan hanya sebagai sejumlah mata pelajaran yang harus ditempuh atau diselesaikan siswa di sekolah atau di perguruan tinggi. Secara lebih luas kurikulum diartikan tidak terbatas pada mata pelajaran saja, tetapi lebih luas daripada itu, kurikulum diartikan merupakan aktivitas apa saja yang dilakukan di sekolah dalam rangka mempengaruhi anak dalam belajar untuk mencapai suatu tujuan, termasuk di dalamnya kegiatan belajar mengajar, mengatur strategi dalam proses belajar, cara mengevaluasi program pengembangan pengajaran. Kurikulum merupakan inti dari proses pendidikan di sekolah. Pelaksanaan kurikulum langsung berpengaruh terhadap hasil pendidikan. Kurikulum sangat menentukan proses dan hasil suatu sistem pendidikan. Kurikulum juga bisa berfungsi sebagai media untuk mencapai 
tujuan sekaligus sebagai pedoman dalam pelaksanaan pengajaran pada semua jenis dan semua tingkat pendidikan. (Muhammedi, 2016:68). Kurikulum digunakan untuk acuan pengalaman pembelajaran siswa, diperlihatkan dalam pembentukan tujuan, rencana, dan rancangan untuk pembelajaran dan pengimplementasian dari rencana-rencana tersebut dan rancangan dalam lingkungan sekolah. (Pardana, 2013:65).

Dengan demikian, kurikulum merupakan hal yang pokok dalam dunia pendidikan. Hal-hal yang berhubungan dengan pencapaian tujuan pendidikan dipandang sebagai kurikulum. Pengertian kurikulum yang semakin meluas, sehingga membuat para pelaksana kurikulum memberikan batasan sendiri terhadap kurikulum. Namun perbedaan pengertian tersebut tidak menjadi masalah yang besar terhadap pencapaian tujuan pendidikan, apabila kurikulum tetap berpegang pada prinsip-prinsip yang mendasarinya,. Perwujudan prinsip, aspek dan konsep kurikulum tersebut terletak pada guru. Sehingga guru memiliki tanggung jawab terhadap tercapainya tujuan kurikulum itu sendiri.

Tulisan ini menggunakan metode berupa kajian teori mengenai prinsip pengembangan kurikulum. Teori merupakan penjelasan kejadian sosial atau fenomena dalam perumusan antar variabel yang dihubungkan secara sistematis dari serangkaian definisi, konstruk, konsep, asumsi dan proposisi. Dalam teori terkandung beberapa hal sebagai berikut, yaitu:

1) Konsep-konsep yang berkaitan dirangkai dalam satu proposisi.

2) Penentuan hubungan antar konsep secara sistematis untuk menjelaskan fenomena.

3) Penentuan konsep mana yang berkaitan dengan konsep tertentu untuk menjelaskan fenomena tertentu.

Teori-teori yang dikemukakan dalam tulisan ini adalah pengertian kurikulum dan pengembangnya, ditambah teori mengenai sumber dan prinsip pengembangan kurikulum, pembelajaran serta evaluasi dari pengembangan kurikulum. Teori-teori tersebut dirangkum dan dicari benang merahnya sehingga dapat dikemukakan pembahasan mengenai komponen pengembangan kurikulum. Sementara tujuan dari pembuatan tulisan ini adalah :
1) Memahami pengertian kurikulum
2) Memahami sumber-sumber kurikulum
3) Memahami tipe-tipe kurikulum
4) Memahami prinsip-prinsip pengembangan kurikulum 


\section{PEMBAHASAN}

Pengembangan kurikulum adalah sebuah proses yang merencanakan, menghasilkan suatu alat yang lebih baik dengan didasarkan pada hasil penilaian terhadap kurikulum yang telah berlaku, sehingga dapat memberikan kondisi belajar mengajar yang baik. Dengan kata lain pengembangan kurikulum adalah kegiatan untuk menghasilkan kurikulum baru melalui langkah-langkah penyusunan kurikulum atas dasar hasil penilaian yang dilakukan selama periode waktu tertentu. Prinsip kurikulum dapat juga dikatakan sebagai aturan yang menjiwai pengembangan kurikulum. Prinsip tersebut mempunyai tujuan agar kurikulum yang didesain atau dihasilkan sesuai dengan permintaan semua pihak yakni anak didik, orang tua, masyarakat dan bangsa. Pada umumnya ahli kurikulum memandang kegiatan pengembangan kurikulum sebagai suatu proses yang berkesinambungan, merupakan suatu siklus yang menyangkut beberapa kurikulum yaitu komponen, tujuan, bahan, kegiatan dan evaluasi.

Pengembangan kurikulum pada hakekatnya adalah proses atau kegiatan yang disengaja dan dipikirkan untuk menghasilkan sebuah kurikulum sebagai pedoman dalam proses dan penyelenggaraan pembelajaran oleh guru di sekolah. (Sanjaya, 2011:32). Pengembangan kurikulum bermakna mengarahkan kurikulum sekarang ke tujuan pendidikan yang diharapkan karena adanya berbagai pengaruh yang sifatnya positif yang datangnya dari luar atau dari dalam sendiri dengan harapan agar peserta didik dapat menghadapi masa depannya dengan baik. (Dakir, 2010:91). Terdapat empat unsur yang perlu diperhatikan dalam pengembangan, yaitu:

1) Merencanakan, merancang dan memprogramkan bahan ajar dan pengalaman belajar.

2) Karakteristik peserta didik.

3) Tujuan yang akan dicapai.

4) Kriteria-kriteria untuk mencapai tujuan.

Pengembangan kurikulum adalah istilah yang komprehensif, yang di dalamnya mencakup perencanaan, penerapan dan evaluasi. Perencanaan kurikulum adalah langkah awal membangun kurikulum ketika pekerja kurikulum membuat keputusan dan mengambil tindakan untuk menghasilkan perencanaan yang akan digunakan oleh guru dan peserta didik. Penerapan Kurikulum atau biasa disebut juga implementasi kurikulum berusaha mentransfer perencanaan kurikulum ke dalam tindakan operasional. Evaluasi kurikulum merupakan tahap 
akhir dari pengembangan kurikulum untuk menentukan seberapa besar hasilhasil pembelajaran, tingkat ketercapaian program-program yang telah direncanakan, dan hasil-hasil kurikulum itu sendiri. Dalam pengembangan kurikulum, tidak hanya melibatkan orang yang terkait langsung dengan dunia pendidikan saja, namun di dalamnya melibatkan banyak orang, seperti : politikus, pengusaha, orang tua peserta didik, serta unsur-unsur masyarakat lainnya yang merasa berkepentingan dengan pendidikan.

Dalam proses pengembangan kurikulum, selain harus memiliki landasan yang kuat juga harus memiliki prinsip-prinsip yang jelas. Prinsip-prinsip dasar pengembangan kurikulum berkedudukan sebagai petunjuk langsung dalam kegiatan pendidikan dan dalam bidang-bidang lainnya. Prinsip-prinsip tersebut bersumber pada :

1) Hasil data empirik

2) Hasil dari idea tau gagasan masyarakat dalam sikap dan kepercayaan

3) Berdasarkan akal sehat.

Prinsip-prinsip yang akan digunakan dalam kegiatan pengembangan kurikulum pada dasarnya merupakan kaidah-kaidah atau hukum yang akan menjiwai suatu kurikulum. Dalam pengembangan kurikulum, dapat menggunakan prinsip-prinsip yang telah berkembang dalam kehidupan seharihari atau justru menciptakan sendiri prinsip-prinsip baru. Oleh karena itu, dalam implementasi kurikulum di suatu lembaga pendidikan sangat mungkin terjadi penggunaan prinsip-prinsip yang berbeda dengan kurikulum yang digunakan di lembaga pendidikan lainnya, sehingga akan ditemukan banyak sekali prinsipprinsip yang digunakan dalam suatu pengembangan kurikulum. Terdapat jenisjenis prinsip dasar dalam pengembangan kurikulum, dimana prinsip dasar ini dipandang sebagai pandangan dasar yang benar dalam pengembangan kurikulum. Jenis-jenis prinsip ini dapat dibedakan oleh tingkat keefektifannya yang diketahui melalui tingkat resikonya. Pemahaman akan perbedaan ini sangat penting sebelum menetapkan prinsip-prinsip dasar untuk pengembangan sebuah kurikulum. Jenis-jenis prinsip dasar dalam pengembangan kurikulum antara lain:

1) Kebenaran keseluruhan

Kebenaran keseluruhan adalah kebenaran yang jelas atau terbukti lewat eksperimen atau uji coba, dan alasan tersebut diterima tanpa hambatan. Sebagai contoh, pembahasan yang berarti dapat membantu siswa untuk mengetahui aturan-aturan dan mengalami kemajuan dengan mengerti 
keterampilan-keterampilan sebagai syarat mutlak dari pemahaman yang mendasar akan menghadirkan latihan-latihan yang bermakna.

2) Kebenaran bagian

Kebenaran bagian ini maksudnya adalah kebenaran berdasarkan data yang terbatas dan bisa diaplikasikan pada situasi tertentu dan tidak bersifat umum. Seperti ada sebagian tenaga-tenaga pengajar berpendapat bahwa pencapaian prestasi siswa akan lebih tinggi ketika siswa itu dikelompokkan pada jenjang yang sama dalam proses pembelajaran.

3) Dugaan

Sebagian prinsip-prinsip dasar tidak semuanya benar, bisa juga merupakan dugaan atau uji coba, sementara ide-ide atau dugaan-dugaan tersebut menjadi dasar keputusan dalam pengembangan kurikulum.

Sumber-sumber pengembangan kurikulum dapat berupa apa saja baik materiil ataupun non materiil, baik yang bersifat ilmiah maupun non ilmiah, baik dari internal maupun eksternal lembaga pendidikan dan pengembangan kurikulum. Sumber-sumber ini meliputi segala hal yang dapat mempengaruhi bahkan menjadi bagian dari unsur-unsur yang ada pada kurikulum baik pada landasan, komponen, organisasi, prinsip dari perubahan atau perkembangan kurikulum. (Armiadi, 2017:196). Terdapat empat sumber prinsip pengembangan kurikulum, yaitu:

1) Data empiris

Data empiris adalah data yang ditemukan atau disimpulkan dari sebuah eksperimen atau penelitian. ilmu dan penelitian pada zaman modern sekarang ini memiliki kiblat empiris. Segala penemuan atau bukti harus berdasarkan penelitian atau eksperimen secara inderawi. Perbedaan dengan penggunaan dalam bidang filsafat yang biasanya disebut empirisme/ empirisisme mengacu pada hipotesis yang dapat diteliti dan dibuktikan kebenarannya melalui observasi atau eksperimen.

2) Data eksperimen

Data yang didapat dari hasil penelitian eksperimen untuk mengetahui akibat yang ditimbulkan dari suatu perlakuan yang diberikan secara sengaja oleh peneliti.

3) Cerita atau legenda yang hidup dalam masyarakat (folkore of curriculum). 
Banyak data-data lainnya yang diperoleh bukan dari hasil penelitian yang di gunakan juga terbukti efektif untuk memecahkan masalah-masalah kehidupan yang kompleks diantaranya yaitu adat kebiasaan yang hidup di masyarakat (folklore of currikulum) dan hasil pertimbangan dan penilaian akal pikiran (common sens). Bahkan data yang diperoleh dari penelitian sendiri digunakan setelah melalui proses pertimbangan dan penilaian akal sehat terlebih dahulu.

Pengembangan kurikulum memiliki dua prinsip pokok yaitu prinsip umum dan juga prinsip khusus. Prinsip umum dalam pengembangan kurikulum antara lain:

\section{1) Relevansi}

Ada dua macam relevansi yang harus dimiliki kurikulum, yaitu relevansi keluar dan relevansi di dalam kurikulum itu sendiri. Relevansi ke luar dapat diartikan isi, tujuan, proses pembelajaran yang tercakup dalam kurikulum hendaknya relevan dengan tuntutan, kebutuhan, dan perkembangan masyarakat. Kurikulum menyiapkan siswa untuk siap hidup bermasyarakat dan di dunia kerja. Apa yang tertuang dalam kurikulum hendaknya mempersiapkan siswa untuk tugas tersebut. Kurikulum bukan hanya mempersiapkan siswa untuk menghadapi perjalanan hidup sekarang tetapi juga yang akan datang. Kurikulum juga harus memiliki relevansi di dalam yaitu ada kekonsistenan antara komponen-komponen kurikulum yaitu antara isi, tujuan dan proses pembelajaran, penyampaian dan penilaian. Relevansi internal ini menunjukkan suatu keterpaduan kurikulum.

2) Fleksibilitas

Kurikulum hendaknya memiliki sifat lentur atau fleksibel. Kurikulum mempersiapkan anak untuk kehidupan sekarang dan yang akan datang, di sini dan di tempat lain, bagi anak yang memiliki latar belakang dan kemampuan yang berbeda. Suatu kurikulum yang baik adalah kurikulum yang berisi hal-hal yang solid, tetapi dalam pelaksanaannya memungkinkan terjadinya penyesuaian-penyesuaian berdasarkan kondisi daerah, waktu maupun kemampuan, dan latar belakang.

3) Kontinuitas

Perkembangan dan proses pembelajaran berlangsung secara berkesinambungan, tidak terputus-putus atau terhenti oleh karena itu pengalaman-pengalaman yang disediakan kurikulum hendaknya 
berkesinambungan antara satu tingkat kelas dengan kelas lainnya, antara satu jenjang pendidikan dengan jenjang yang lain, juga dengan jenjang pendidikan dengan pekerjaan. Perkembangan kurikulum perlu dilakukan serempak bersama-sama, perlu selalu ada komunikasi dan kerja sama antara para pengembangan kurikulum pendidikan dasar dengan pendidikan mengengah dan juga pendidikan tinggi.

4) Praktis

Betapapun bagus dan idealnya suatu kurikulum kalau menurut keahlian dan peralatan yang sangat khusus dan mahal pula biayanya, maka kurikulum dan pendidikan selalu dilaksanakan dalam keterbatasan, baik keterbatasan waktu, biaya, alat, maupun personalia. Kurikulum bukan hanya harus ideal tetapi juga praktis.

5) Efektifitas

Efektivitas dalam suatu kegiatan berkenaan dengan sejauh mana apa yang direncanakan dapat terlaksana. Dalam bidang pendidikan, efektivitas ini dapat dilihat dari segi efektivitas guru mengajar dan subyek didik belajar. Sementara dalam rangka pengelolaan kurikulum dan pengembangannya, usaha untuk meningkatkan efektivitas kegiatan belajar subyek didik dilakukan dengan memilih jenis-jenis metode dan alat yang dipandang paling ampuh dalam mencapai tujuan yang diinginkan.

Sementara prinsip khusus berhubungan dengan prinsip yang hanya berlaku pada tempat-tempat tertentu dan pada situasi tertentu saja. Prinsip khusus ini lebih mengarah pada prinsip digunakan pada saat pengembangan kurikulum yang secara khusus (tujuan, isi, metode dan evaluasi). Misalnya pada salah satu jenis dan jenjang pendidikan yang ada dengan jenis dan jenjang pendidikan yang lainnya memiliki karakteristik yang berbeda pada beberapa aspek aspeknya. Perbedaan yang seperti ini juga dapat mengakibatkan adanya penggunaan prinsip yang khas yang mana prinsip ini sesuai dengan situasi dan kondisi di tempat, serta karakteristik dari jenis dan jenjang pendidikannya tersebut (Kusumawati dan Rulviana, 2017). Prinsip khusus yang terdapat dalam pengembangan kurikulum lainnya yaitu prinsip pengembangan komponen-komponen kurikulum, yang mana satu komponen dengan komponen yang lainnya memiliki prinsip yang tidak sama. Berikut terdapat beberapa prinsip pengembangan kurikulum khusus yang dikemukakan oleh Sukmadinata dan Muchlis (2000), 
yaitu:

1) Prinsip yang berkenaan dengan tujuan dari pendidikan.

Tujuan dari pendidikan yang dimaksud adalah tujuan yang bersifat umum (jangka panjang), jangka pendek (khusus), dan juga jangka menengah. Perumusan dari tujuan pendidikan ini bersumberkan dari ketentuanketentuan dan kebijakan-kebijakan dari pemerintah yang dapat ditemukan pada dokumen lembaga negara mengena tujuan dan juga strategi dalam pembangunan yang juga termasuk didalamnya pendidikan; survei terhadap persepsi orang tua dan juga masyarakat mengenai apa yang mereka butuhkan dengan cara mewawancarai mereka maupun melalui angket; survei tentang pandangan para ahli dalam bidang-bidang tertentu yang dihimpun melalui angket, melalui wawancara, melalui observasi, maupun dari berbagai media masa; survei tentang sumber daya manusia; pengalaman pihak dalam masalah yang sama; serta hasil-hasil dari penelitian.

2) Prinsip yang berkenaan dengan pemilihan isi pendidikan.

Memilih isi pendidikan sesuai dengan kebutuhan pendidikan yang telah ditentukan oleh para perencana kurikulum yang memerlukan pertimbangan beberapa hal :

a) Memerlukan penjabaran tujuan dari pendidikan dan pengajaran ke dalam bentuk perbuatan hasil belajar yang khusus dan sederhana. Makin umum suatu perbuatan hasil belajar dirumuskan semakin sulit menciptakan pengalaman belajar.

b) Isi bahan pelajaran harus meliputi segi pengetahuan, sikap, dan keterampilan

c) Unit-unit kurikulum harus disusun dalam urutan yang logis dan juga sistematis. Ketiga ranah belajar, yaitu pengetahuan, sikap, dan keterampilan diberikan secara simultan dalam urutan situasi belajar. Untuk hal tersebut diperlukan buku pedoman guru yang memberikan penjelasan tentang organisasi bahan dan alat pengajaran secra lebih mendetail.

3) Prinsip yang berkenaan dengan pemilihan proses belajar mengajar.

Pemilihan proses belajar mengajar yang digunakan perlu memperhatikan hal-hal sebagai berikut :

a) Apakah metode atau teknik belajar mengajar yang digunakan cocok untuk mengajarkan bahan pelajaran? 
b) Apakah metode atau teknik tersebut memberikan kegiatan yang bervariasi sehingga dapat melayani perbedaan individual siswa?

c) Apakah metode atau teknik tersebut memberikan urutan kegiatan yang bertingkat-tingkat?

d) Apakah metode atau teknik tersebut dapat menciptakan kegiatan untuk mencapai tujuan kognitif, afektif dan psikomotor?

e) Apakah metode atau teknik tersebut lebih mengaktifkan siswa, atau mengaktifkan guru atau kedua-duanya?

f) Apakah metode atau teknik tersebut mendorong berkembangnya kemampuan baru?

g) Apakah metode atau teknik tersebut menimbulkan jalinan kegiatan belajar di sekolah dan di rumah, juga mendorong penggunaan sumber yang ada di [rumah dan di masyarakat?

h) Untuk belajar keterampilan sangat dibutuhkan kegiatan belajar yang menekankan "learning by doing" disamping "learning by seeing and knowing".

4) Prinsip yang berkenaan dengan media dan alat bantu dalam pengajaran.

Dalam mewujudkan proses pembelajaran yang efektif dan efisien maka harus memerlukan dukungan dari penggunaan media dan alat bantu dalam belajar dengan tepat. Berikut ini beberapa prinsip yang dapat dijadikan sebuah pegangan dalam memilih maupun menggunakan media dan alat bantu dalam belajar :

a) Jika ada yang hendak dibuat, maka kita harus memperhatikan terlebih dahulu bagaimana cara pembuatan nya, siapa yang membuatnnya, serta biaya dan waktu dalam pembuatannya.

b) Bagaimana pengorganisasian media dan alat bantu pembelajaran, apakah berbentuk modul, ataukah berbentuk yang lainnya?

c) Media dan alat bantu dalam belajar apakah yang dibutuhkan didalam proses pembelajaran, apakah sudah tersedia semua? Dan apakah sudah ada alat penggantinya apabila alat yang dicari tidak ada?

d) Bagaimana pengintegrasiannya di dalam seluruh kegiatan belajar?

e) Hasil yang terbaik akan diperoleh dengan menggunakan multi media.

5) Prinsip yang berkenaan dengan evaluasi.

Evaluasi adalah bagian yang tidak terpisahkan dari suatu pembelajaran. Maka dari itu, di dalam pengembangan kurikulum ini haruslah 
memperhatikan prinsip-prinsip evaluasi, adapun prinsip evaluasinya yaitu komprehensif, objektivitas, mendidik, kooperatif, akuntabilitas, dan juga praktis. Dalam praktiknya, terdapat lima fase yang harus diperhatikan pengembang kurikulum dalam kegiatan evaluasinya, yaitu terkait perencanaan evaluasi, pengembangan alat evaluasi, pengumpulan data, pengolahan hasil evaluasi, laporan dan pemanfaatan hasil dari evaluasi.

\section{PENUTUP}

Prinsip kurikulum diartikan sebagai aturan yang menjiwai pengembangan kurikulum. Prinsip tersebut mempunyai tujuan agar kurikulum yang didesain atau dihasilkan sesuai dengan permintaan semua pihak yakni anak didik, orang tua, masyarakat dan bangsa. Sumber prinsip perkembangan kurikulum terdiri dari data empiris, data eksperimen, cerita atau legenda yang hidup di masyarakat, akal sehat. dengan hal ini prinsip dalam perkembangan kurikulum dapat di kelompokkan menjadi dua pokok utama yaitu prinsip umum yang terdiri dari prinsip relevansi, prinsip fleksibilitas, kontinuitas, praktis, dan prinsip efektif. Prinsip khusus terdiri dari prinsip berkenaan dengan tujuan pendidikan, Prinsip berkenaan dengan pemilihan isi pendidikan, Prinsip berkenaan dengan pemilihan proses belajar mengajar, Prinsip berkenaan dengan pemilihan media dan alat pengajaran, dan Prinsip berkenaan dengan pemilihan kegiatan penilaian.

\section{DAFTAR PUSTAKA}

Armiadi. 2017. "Pengembangan Landasan Kurikulum Pendidikan". Al-Mabhats: Jurnal Penelitian Sosial Agama Volume 2 Nomor 2017.

Dakir. 2010. Perencanaan dan Pengembangan Kurikulum. Jakarta: Rineka Cipta.

Kusumawati, N dan V. Rulviana. 2017. Pengembangan Kurikulum di Sekolah Dasar. Magetan: AE Media Grafika.

Muhammedi. 2016. "Perubahan Kurikulum di Indonesia: Studi Kritis Tentang Upaya Menemukan Kurikulum Pendidikan Islam yang Ideal”. RAUDHAH Volume IV Nomor 1 Januari-Juni 2016 hal. 49-70. 
Pardana, D.I. 2013. Kurikulum dan Pendidikan di Indonesia: Proses Mencari Arah Pendidikan yang Ideal di Indonesia. Jurnal Pemikiran Sosiologi Volume 5 Nomor 1 Mei 2013.

Sanjaya, W. 2011. Kurikulum dan Pembelajaran. Bandung: Kencana Prenada Media.

Sukmadinata, N.S dan Muchlis. 2000. Pengembangan Kurikulum: Teori dan Praktek. Bandung: Remaja Rosdakarya. 